\title{
Reappraisal of Antimalarials in Interferonopathies: New Perspectives for Old Drugs
}

Special Theme Issue "Perspectives on rational drug design and therapy for pediatric precision medicine"

Elisa Piscianz ${ }^{\mathrm{a}}$, Eva Cuzzoni $^{\mathrm{b}}$, Rajan Sharma $^{\mathrm{c}}$, Alessandra Tesser $^{\mathrm{a}}$, Pooja Sapra $^{\mathrm{d}}$, Alberto Tommasini $^{\mathrm{e}}$

${ }^{\mathrm{a}}$ Department of Medicine, Surgery and Health Sciences, University of Trieste, Trieste, Italy; ${ }^{\mathrm{b}}$ Department of Life Sciences, University of Trieste, Trieste, Italy; ${ }^{\mathrm{c}}$ Head of Research and Content, ayurajan, India; ${ }^{\mathrm{d}}$ Department of Chemistry, CSSS(PG) College, Machhra, Meerut, India; ${ }^{\mathrm{e}}$ Department of Paediatrics, Institute for Maternal and Child Health - IRCCS Burlo Garofolo, Trieste, Italy 


\section{Abstract}

The story of antimalarials as antinflammatory drugs dates back few centuries. Chinin, the extract of the Cinchona bark, has been exploited since the 18th century for its antimalarial and antifebrile properties. Later, during the Second World War, the broad use of antimalarials allowed arguing their antirheumatic effect on soldiers. Since then, these drugs have been broadly used to treat Systemic Lupus Erythematosus, but, only recently, the molecular mechanisms of action have been partly clarified.

The inhibitory action on vacuole function and trafficking has been considered for decades the main mechanism of the action of antimalarials, affecting the activation of phagocytes and dendritic cells. In addition, chloroquine is also as a potent inhibitor of autophagy, providing another possible explanation of its antinflammatory action. However, much attention has been recently devoted to the action of antimalarials on the so-called cGAS-STING pathway deputed to the sensing of nucleic acid and to the production of type 1 interferons. This pathway is a fundamental mechanism for host defence, since it is able to detect microbial DNA and RNA and induce the immune response that will lead to the production of interferons. Of note, genetic defects in disposal of nucleic acids lead to inappropriate activation of the cGAS-STING pathway and inflammation. These disorders, named type I interferonopathies, represent a valuable model to study the antinflammatory potential of antimalarials.

We will discuss possible development of antimalarials to improve the treatment of type I interferonopathies and, likely multifactorial disorders characterised by interferon inflammation, such as systemic lupus erythematosus.

Keywords: Antimalarials; Autoimmunity; Autoinflammatory diseases; Interferonopathies; Interferon Signature; Cyclic GMP-AMP Synthase; Systemic Lupus Erythematosus; Type Interferons. 


\section{Story of antimalarials: from Cinchona bark to Atabrine}

The first antimalarial (AM) drug discovered was the extract from the bark of Chincona tree, a plant of the tropical Latin America (Cinchona succirubra). Since the 18th century, use of this extract has become an efficient therapeutic tool to eradicate malaria from endemic zones and its efficacy was so evident that Chincona was also used to define intermittent fever due to Plasmodium (Francesco Torti “Therapeutice specialis ad febres quasdam perniciosas", 1712) [1, 2]. For almost a century the treatment has been used empirically, by extracting the alkaloid (quinine) from the bark without clear indication on purity and concentration. Nonetheless, the efficacy in treating the fever was so noticeable that its use rapidly and widely expanded in almost all the world between the 18th and 20th centuries. The purification of quinine represented also a great pharmaceutical industry success [3], so that malaria could be considered the first infectious disease treated with a pure chemical compound [4].

In 1820 quinine was finally isolated from the bark [5]. But, only by the end of 1800 strategies for synthesis of quinine alkaloids have developed [6] and became an industrial process during the Second World War, when it has strived to produce synthetic AM treatments for the soldiers [3]. This also led to the synthesis of acridine, from which mepacrine (commercialized as Atabrine) was developed becoming another fundamental AM drug [7].

In the meanwhile, in the years between the 19th and 20th centuries, the etiopathology of malaria was discovered with the identification of Plasmodium and some of the new synthesized compounds could be tested and modified to obtain more effective and less toxic drugs, achieving the synthesis of a compound, resochin, later called Chloroquine (CQ), that shows a higher efficacy compared to mepacrine [7, 8].

During war, the wide use of AM drugs on soldiers allowed discovering their "side" antinflammatory effects, particularly on arthritis and skin lesions of rheumatic diseases [9, 10]. Within the middle of 20th century, systematic studies on AMs in rheumatic diseases have been performed and scientific evidences were published [11-13]. Since then, AMs have been used to treat with success rheumatic disorders, even if, at today, the mechanisms of action of AM drugs as antinflammatories and immunomodulators is not completely unravelled.

\section{Interferonopathies: from monogenic Aicardi-Goutieres Syndrome to Systemic Lupus Erythematosus}

Monogenic interferonopathies

Interferonopathies are a group of disorders arising from inappropriate production of type I interferons. The term interferonopathy was firstly proposed to describe the central role of a dysregulated production of type I interferons in the pathogenesis of Aicardi Goutieres Syndrome (AGS), spondyloenchondrodysplasia (SPENCD), and cases of systemic lupus erythematosus (SLE) [14] Subsequently, IFN-mediated autoinflammatory disorders, such as STING-associated vasculopathy with onset in infancy (SAVI) and Chronic Atypical Neutrophilic Dermatosis with Lipodystrophy and Elevated temperature (CANDLE) have been included in this group [15]. These disorders are named autoinflammatory as they are characterized by seemingly unprovoked upregulation of innate immunity and inflammation.

Most of the genes responsible for interferonopathies are involved in mechanisms of recognition and/or metabolism of nucleic acids, that physiologically prevent the accumulation of nucleic acids in the cytoplasm (Table 1). 
Table 1. Diseases with dysregulated interferon pathway ${ }^{a}$.

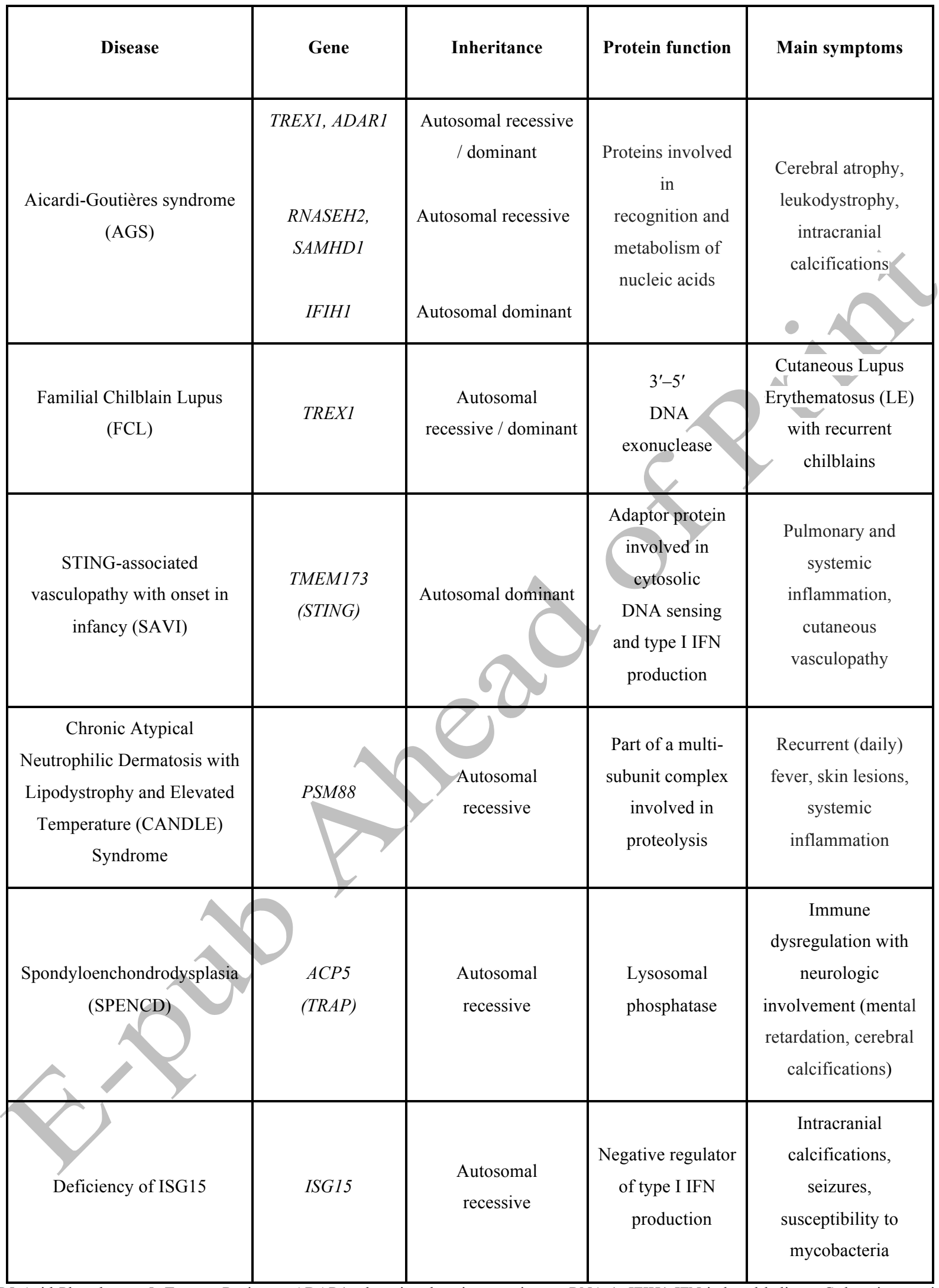

ACP5 Acid Phosphatase 5, Tartrate Resistant; ADAR1 adenosine deaminase acting on RNA 1; IFIH1 IFN-induced helicase C domain-containing protein 1 (also known as MDA5); IFN Interferon; ISG15 Interferon-stimulated gene 15; PSMB8 Proteasome subunit beta type-8, RNASEH2 Ribonuclease H2; SAMHD1 deoxynucleoside triphosphate triphosphohydrolase SAM domain and HD domain 1; TMEM173 transmembrane Protein 173 (STING Stimulator of interferon genes); TREX1 DNA 3' - repair exonuclease 1.

${ }^{a}$ Modified from [16] and [34]. 
The first disease associated with the term "interferonopathy" was the AGS, an early onset progressive brain disease associated with increased number of white blood cells in the cerebrospinal fluid and skin lesions (in some cases, the disease shows an overlap with SLE), caused by mutations that alters the function of nucleases that degrade DNA (TREX1) and DNA:RNA hybrid molecules (RNASE H2 complex) [16-19]. Later, different mutations have been associated with other form of AGS: ADAR1, an RNA editing enzyme [20]; SAMHD1, a protein that decreases the availability of cytosolic deoxynucleotides (dNTPs) [21]; IFIH1, a cytosolic viral RNA receptor [22, 23]. SAVI syndrome, vasculopathy that produces severe skin lesions (face, ears, nose, and digits), is due to activating mutations in the adapter protein Stimulator of Interferon Genes (STING), responsible for constitutive type I IFN production [24]. Finally, a different mechanism is involved in Interferon stimulated gene-15 (ISG15) disorder, characterized by intracranial calcifications, epilepsy, high susceptibility to mycobacterial infections, autoantibodies and elevated levels of interferon and interferon-induced genes. In this case, the ISG15 defect affects the suppressive mechanism that tightly regulates the type I interferon cascade, resulting in a lack of "switching off" signal [25].

Summarizing, some interferonopathies depend on a defective degradation of endogenous nucleic acids in lysosomes and/or in the cell cytoplasm; other diseases arise from a constitutive activation or defective regulation of downstream effector molecules in the nucleic acids sensing pathways. This may be highly relevant to the choice of antinflammatory agents acting on different points of the interferon pathway.

Similar to what described for other autoinflammatory diseases, innate immune mechanisms devoted to the sensing of danger signals are activated in the absence of exogenous infectious triggers. However, whilst IL1 $\beta$-associated autoinflammatory diseases display little if any involvement of adaptive immunity, interferonopathies can associate with secondary activation of B cells and production of autoantibodies. Thus, the dogma that autoinflammatory diseases are not characterized by autoimmune phenomena does not apply to all the interferonopathies, which may include autoinflammatory disorders as well as diseases with more prominent autoimmune features [26].

Although all the interferonopathies are due to mutations in the same pathway, the expression of the defect in different tissues and cell compartments may account for a wide clinical spectrum of symptoms, ranging from TORCH-like neonatal-onset inflammatory diseases with neurologic and multi-organ involvement to familial systemic lupus erythematosus. The finding of a strongly upregulated expression of genes induced by interferon has constituted the basis for the definition of the so called Interferon Signature (IS), which has become a powerful screening tool for interferonopathies [27]. IS consists in the increased expression of set of genes induced by interferon (Interferon stimulated genes, ISGs), which can be analyzed in the peripheral blood through qPCR technique. The median value of the relative quantifications provides a "score", useful to identify a positive or negative IS, and, respectively, if the interferon pathway is activated or not [27].

Of note, a strong IS can be found in many patients with SLE, supporting the idea that a dysregulated activation of the interferons also plays a crucial role in this multifactorial disorder [28].

For these reasons, much interest has been drawn toward the study of the pathway involved in monogenic interferonopathies. Recent studies highlighted the crucial role of the enzyme Cyclic GMP-AMP Synthase (cGAS) as the main initiator of the DNA sensing in the cells [29]. Undigested cytoplasmic DNA stimulates cGAS to produce the second mediator cyclic GMP-AMP (cGAMP) [30], which in turn leads to activation of STING [31], phosphorylation of TBK1 and translocation of the transcription factor IRF3 to the nucleus, where it induces the production of type I interferons [32, 33]. In normal conditions, this sequence of events is meant to sense the presence of viral nucleic acids and to initiate the antiviral immune response, sustained by the production of interferons. In monogenic interferonopathies and in SLE, this pathway is inappropriately activated producing a chronic inflammatory response. Clinical features common to most 
interferonopathies may include skin vasculopathy with chilblains and livedo reticularis, interstitial lung disease and panniculitis [34]. Neurological, articular and renal involvement is also common. Furthermore, the effect of interferons on the bone marrow can be responsible for various degrees of blood cells cytopenia. In some cases, anti-nuclear and antiDNA antibodies may result from an abnormal exposure of the immune system to undigested nucleic acids and from a chronic stimulation of antibody producing B cells by interferon activated dendritic cells. Even if a number of other pathogenic mechanisms may variously contribute to the development of SLE, the amplification of the inflammatory response by interferons seems to be a crucial mechanism in the pathogenesis of this disease. Thus, there is much interest on the development of pharmacologic approaches to modulate the innate response to nucleic acids in SLE. The study of monogenic interferonopathies will provide valuable models to measure the potential of different inhibitors on this pathway.

\section{Dysregulated interferon pathway in lupus and other multifactorial rheumatic disorders}

The pathological role of type I interferon pathway has been reported not only for monogenic interferonopathies, but also for some multifactorial rheumatic disorders such as systemic lupus erythematosus (SLE) and dermatomyositis (DM).

SLE is characterized by skin rashes, arthritis, kidney and blood disorders and by the presence of numerous autoantibodies (auto-Ab), in particular directed against components of the nucleus, the cytoplasm, the cell surface and against soluble molecules such as Ig and coagulation factors [35].

In recent years, the role of innate immunity has emerged in the pathogenesis of SLE, and more than 30 genetic variants have been associated with SLE diagnosis, including variants of HLA, Fc $\gamma$ receptor genes, IRF5, STAT4, PTPN22, TNFAIP3. Some of those genes are related to regulation of endogenous nucleic acids (e.g. genes identified from the study of the AGS as TREX1 and the RNASE H2 family, which, in some cases, are associated with SLE), or TLR-activating immune complexes and their downstream signaling molecules. The peculiar feature shared by most of these mechanisms is the strong induction of type I IFN $[27,36]$. Observations of elevated levels of type I IFN in the blood of patients with SLE were initially reported in 1979 [37], but for years a few groups have investigated the role of type I IFN in SLE. In 2002, the first gene expression data from different studies performed in peripheral blood mononuclear cells (PBMC) from lupus patients was reported [38-40]. In the following years, thanks to the development of in vitro and murine models [41, 42], type I IFN has been identified as a central pathogenic mediator responsible for many of the peculiar features of SLE $[43,44]$. Moreover, while in viral infections, type I IFN is produced in the initial stage but is not persistent, in patients with SLE the type I IFN gene expression signature persists over time [45-47]. Finally, another evidence of a pathogenic role for type I IFN in SLE comes from analysis of tissues: the IFN-induced gene transcripts were found in skin and renal biopsies and in synovial tissue [48-50].

Another condition in which a strong activation of the type I IFN signal occurs is dermatomyositis (DM), an autoimmune disease affecting principally the skin and the skeletal muscle, which can be discriminate into juvenile dermatomyositis (JDM) and adult dermatomyositis (DM), two different diseases with a different range of additional features and complications. In general, adult patients with DM develop frequently interstitial lung disease, showing higher association with malignancy and other comorbidities, while children with DM display more vasculopathy, but a better prognosis and survival. Despite DM and JDM represent two heterogeneous diseases, they share similar muscle biopsy features and a strong IS in the affected tissues [51, 52].

The evidence of the IFN involvement in the pathogenesis of DM is suggested by different studies that demonstrated the abundance of type I IFN-inducible transcripts in blood samples and/or muscle of DM patients [53, 54]. In 2010, Salajegheh and collaborators showed that the ISG15 transcript, an interferon-induced gene, is highly present in 
dermatomyositis muscle, and, in turn, the exposure of muscle cell culture to type I IFN produces molecular features similar to those of dermatomyositis muscle [55]. These findings support a crucial role for type I interferons in pathological features of DM [56]. One of the well-known mechanism that induces type I IFN production is the trigger of toll-like receptors (TLR7 and 9) in plasmacytoid dendritic cells (pDCs), specialized in the production of type I IFN, which resulted abundant both in the skin lesions of SLE patients and in the affected muscle cells of DM patients [48, 57].

These evidences establish that type I interferon signal represents the pathogenetic mechanism shared by multifactorial rheumatic diseases like SLE and DM, making this pathway as a candidate for targeted therapies and a possible source of blood biomarkers for disease activity.

\section{Clinical trials of antimalarials in rheumatic disorders}

Even if AMs have been used in rheumatic disorders since decades, knowledge on their antinflammatory mechanisms are still evolving, with significant findings obtained in very recent years. These drugs can be considered effective treatments for rheumatoid diseases such as rheumatoid arthritis (RA) and SLE and several clinical trials were published, but with questionable results due to the small sample sizes using higher drug dosages than those accepted today.

Only during the last decade, a lot of new clinical trials have been published with larger sample sizes and better design, shedding light on efficacy and toxicity of Hydroxychloroquine (HCQ), which showed significant superiority to placebo and a low toxicity profile [58].

Others AM used are CQ, structurally similar to HCQ, and Quinacrine (QC, also known as Mepacrine), which is much less frequently used than the others because of the yellowish skin color caused by treatment [59].

Nowadays, the most common used AM drug in rheumatic diseases is HCQ, which covers the most of all AM prescriptions for rheumatic disorders [60]. Indeed, numerous clinical trials involved the use of HCQ in rheumatic disorders, both as a single treatment and in combination with other antirheumatic drugs (Table 2). Conversely, just few trials of CQ are active, and there is no current trial of QC in rheumatic diseases (Table 3) [61].

Table 2. Clinical trials on Hydroxychloroquine in rheumatic disorders ${ }^{\text {a }}$.

\begin{tabular}{|c|c|c|c|c|c|c|}
\hline & $\begin{array}{c}\text { Not yet } \\
\text { started }\end{array}$ & $\begin{array}{c}\text { Phase I } \\
\text { Trials }\end{array}$ & $\begin{array}{c}\text { Phase II } \\
\text { Trials }\end{array}$ & $\begin{array}{c}\text { Phase III } \\
\text { Trials }\end{array}$ & $\begin{array}{c}\text { Phase IV } \\
\text { Trials }\end{array}$ & Terminated \\
\hline Completed & 0 & 1 & 2 & 15 & 4 & 2 \\
\hline Recruiting & 1 & 0 & 1 & 1 & 6 & 0 \\
\hline \\
Ongoing
\end{tabular}


Table 3. Clinical trials on Chloroquine in rheumatic disorders ${ }^{\mathrm{a}}$.

\begin{tabular}{|c|c|c|c|c|c|c|}
\hline & $\begin{array}{c}\text { Not yet } \\
\text { started }\end{array}$ & $\begin{array}{c}\text { Phase I } \\
\text { Trials }\end{array}$ & $\begin{array}{c}\text { Phase II } \\
\text { Trials }\end{array}$ & $\begin{array}{c}\text { Phase III } \\
\text { Trials }\end{array}$ & $\begin{array}{c}\text { Phase IV } \\
\text { Trials }\end{array}$ & Terminated \\
\hline Completed & 0 & 0 & 0 & 5 & 1 & 0 \\
\hline Recruiting & 0 & 0 & 0 & 1 & 0 & 0 \\
\hline Ongoing & 0 & 0 & 0 & 0 & 0 & 0 \\
\hline
\end{tabular}

\section{Mechanisms of action of antimalarials}

Lysosome and autophagy impairment

It is well known that lysosomes accomplish their function of digestion of phagocytized exogenous materials, mainly thanks to the acid $\mathrm{pH}$ inside the organelles themselves. More recently, a role was recognized for lysosomes as important players for the clearance of endogenous material. This process, called autophagy, was demonstrated to be genetically determined and fundamental for maintaining the homeostasis of the cell, since it allows to degrade or recycle cellular components thus providing new material to renew the cell or energy in case of starvation [62-64].

AM drugs, such as CQ and HCQ, are acidophile substances that can freely pass through the cell membrane and accumulate up to 100 times in the acidic organelles like lysosomes, so that they are indicated as lysosomotropic agents [65-67]. Once in the lysosomes, these drugs are protonated and retained in these organelles where they are able to alter morphology and $\mathrm{pH}$, thus resulting in an impaired functionality. This implies altered processing of proteins and ingested antigens, and this is a significant effect particularly for cells like macrophages, monocytes or dendritic cells since the activity of antigen presentation and MHC loading results strongly defective [67, 68]. It seems that the impairment in lysosomal function can lead to an altered immune function and subsequent lowered production of pro-inflammatory cytokines, such as IL-1, IL6 , TNF- $\alpha$ or IFN- $\gamma[68,69]$.

\section{TLR9 blockade}

Toll-like receptors (TLRs) are a family of cellular sensors deputed to the binding of several PAMPs, such as proteins or nucleic acids. Among the identified human TLRs, TLR9 is an endosomal molecule able to bind to unmethylated DNA from pathogens that infect the host cells. The binding between TLR9 and nucleic acids activates a cascade signaling, via MyD88, which results in production of type I interferons and other cytokines [70]. In autoinflammatory disorders such as SLE, the persistent stimulation with endogenous DNA is thought to cause a continuous activation of the pathway, resulting in a dysregulated production of pro-inflammatory cytokines [71, 72]. AMs may influence the activation of TLR9 by different mechanisms, including the binding to nucleic acids and masking of sequences recognized by TLR9 [73, 74] and the modification of lysosomal $\mathrm{pH}$, which can inhibit the recognition of pathogen associated molecular patterns (PAMPs) by endosomal TLRs like TLR9 [73, 75]. Notably, targeting of toll-like receptors recently emerged as a possible innovative approach to treat SLE [76]. 


\section{cGAS inhibition}

Recent insights into molecular mechanisms of onset of monogenic disorders like AGS have revealed the involvement of the enzyme Cyclic GMP-AMP Synthase (cGAS) as a key molecule $[29,77,78]$. Indeed, as previously discussed, cGAS binds DNA and catalyzes the synthesis of cGAMP, a cyclic dinucleotide, that acts as a second messenger and induces the production of type I interferons and other pro-inflammatory cytokines, through the adaptor protein Stimulator of Interferon Genes (STING) [29]. Recently, a hypothesis of action of AMs on this side has been proposed by unbiased studies. Indeed, AMs such as CQ and HCQ are able to inhibit the binding between DNA and cGAS, thus preventing the activation of the pathway [9].

The finding that quinoline AMs are potent inhibitors of cGAS has opened novel avenues to improve the use of this group of medications in the treatment of interferonopathies and SLE.

\section{Pharmacokinetics and pharmacodynamics of antimalarials: can we improve tissue distribution?}

CQ is a 4-amino quinoline drug, largely used in AM chemotherapy. It's derivative HCQ, in which one of the N-ethyl substituents has been beta-hydroxylated, has similar AM activity, however the latter compound is usually preferred for treatment of rheumatic diseases, because, at the high doses required for these diseases, it's ocular toxicity is less frequent $[79,80]$.

Both drugs have a very good bioavailability after oral administration and are rapidly absorbed from intramuscular and

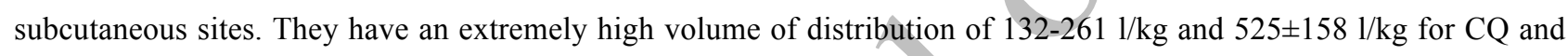
HCQ respectively; indeed, they are extensively distributed and sequestered in tissues, mostly in liver, spleen, kidney, lung and melanin containing cells [81]. Of particular interest is the binding of both drugs to melanin in the pigmented cells of the eye. Studies have shown that the corneal disposition of CQ is higher than HCQ [82, 83]. These deposits in the cornea are dose dependent and are always reversible after discontinuation of the drug. Retinopathy is another important side effect of these AMs [84-86] and is probably related to the binding to melanin in the retinal pigmented epithelium [79]. High concentrations are also found in the brain and spinal cord [81].

CQ is also significantly accumulated in polymorphonuclear-lymphocytes and to a lesser extent in mononuclear and red blood cells and this is particularly interesting in inflammatory diseases. The high concentrations observed in polymorphonuclear blood cells are probably related to the presence of acidic lysosomes in which these drugs, that are weak bases, are trapped [87].

Protein binding is moderate, around 50-60\% [88, 89]. Different studies have demonstrated that CQ, HCQ and their metabolites are excreted and can be found in breast milk, moreover transplacental passage has been also observed [90, 91].

$\mathrm{CQ}$, as well as HCQ, are extensively metabolized and de-alkylated in the liver by cytochrome P450 enzymes and CYP2D8, CYP2D6 and CYP3A4 are the isoforms mainly involved their in metabolism [92]. Desethyl metabolites maintain the pharmacological activity [93, 94].

Both the compounds and their active hepatic metabolites are excreted mostly by the kidney [95, 96]; hence, the dose should be reduced is renal insufficiency, renal excretion can be increased by the acidification of the urines. Small amounts are excreted in feces, through the skin, and in breast milk. These agents have a very long elimination half-life (10-24 and 26-63 days respectively for CQ and HCQ) and are detected in tissues for prolonged periods (up to 5 years) [81].

To date, it is possible to measure plasma, serum and whole blood HCQ levels. Several studies have shown the usefulness of measurements of HCQ levels in particular in patients with SLE [97-101]. 
The other AM drug used in interferonophaties is QC (mepacrine), an acridine derivative. QC is usually administered orally and is rapidly and completely adsorbed from the gastrointestinal tract [102]. The drug can be also administered intralesionary, paralesionary, intravenously, intramuscularly and rectally [103]. Peak plasma levels are reached in 8-12 hours and steady state is reached by the fourth week. Like CQ and HCQ, quinacrine has a high volume of distribution and is concentrated in liver, spleen, lungs and adrenal glands; in the liver, concentrations reach 20,000 times that of plasma [104]. The drug is also highly concentrated in the skin, fingernails and hair [103]. Plasma protein binding at therapeutic doses is $80-90 \%$ and the plasma half-life is five to fourteen days depending on doses regimens [105]. Renal elimination is predominant, while small amounts of the drug are excreted in the feaces, sweat and saliva [103].

The large volume of distribution of AMs results in therapeutic effects but also leads to toxicity, therefore one of the main goals of pharmacology is to specifically target drugs to the cell types responsible for the disease, hence highly increasing the safety of the drug.

To date, a large number of studies have been performed with the aim of specifically targeting drugs: immunoliposomal systems with monoclonal antibodies, sugar-dependent systems that take advantages of cell-specific lectins, and receptordependent systems that allow the targeting of cells bearing specifics integrins have been tested [106-110]. However, these approaches have limited applications and still need to be set up.

In rheumatic diseases, cells of the monocyte-macrophage lines are highly involved and should represent a useful target for therapeutic agents among which AMs. In these cells the intracellular enzyme human carboxylesterases-1 (hCE-1) is high expressed and this is the principal source of the enzyme outside the hepatocytes. Human intracellular carboxylesterases are a family of enzymes that convert neutral membrane esters into charged acid products. Needham $e t$ al [111], developed an interesting model attaching a small esterase-sensitive chemical motif to a wide range of small molecules, in a position that does not significantly interfere with the target enzyme-inhibitor interaction. The authors have demonstrated that these modified compounds are selectively hydrolyzed in monocytes and macrophages by hCE-1, releasing the charged pharmacologically active drug that will be then concentrated in these cell types. The authors successfully uses this approach to deliver a wide range of drugs to cells of the monocytes-macrophage lineage. In human blood, the effect on monocytes of the modified histone deacetylase inhibitors, are evident at concentration 1000 fold lower than those that affect other cells types that do not express hCE-1. It would be of particular interest to apply this approach also on AM drugs used in rheumatic diseases.

\section{Chemical structure of antimalarials: can we improve specificity?}

The structural domains of cGAS present two highly attractive drug targets, the catalytic site and a regulatory site, both with established key residues in relatively compressed regions and both with known substrates/ligands. The pronounced conformational change in the dsDNA bound enzyme compared to apo enzyme lends further enthusiasm to the hypothesis that cGAS activity could be inhibited by appropriately -designed small molecules.

In an effort to identify drugs able to inhibit cGAS activity, researchers performed in silico screening of chemical and drug libraries using the publicly available VINA ${ }^{\mathrm{TM}}$ and DOCK ${ }^{\mathrm{TM}}$ software. Using Computational Analysis with the Autodock VINA $^{\text {TM }}$ platform, researchers identified HCQ, 9-amino-6-chloro-2-methoxyacridine (ACMA) and Quinacrine (QC) to interact at the $\mathrm{Zn}$ thumb and spine regions of cGAS, involving simultaneous enzyme and DNA binding. The two main binding events, at the $\mathrm{Zn}$ thumb and at the spine, appear to occur within 3-10 Angstroms of the amino acids shown by mutation to be needed for dsDNA binding. The binding affinity was calculated by AutoDock VINA ${ }^{\mathrm{TM}}$ software [112, 113]. 
Researchers performed in vitro dose-titration experiments with recombinant cGAS and quantified cGAMP production using thin layer chromatography (TLC). Every tested AM compound yielded dose-response curves similar to QC but with different inhibitory activities [112]. QC and ACMA were the most potent inhibitors of cGAMP production (low $\mu \mathrm{M}$ range); quinine $(\mathrm{QN})$ had very low inhibitory activity, and primaquine (PQ), CQ, and HCQ had intermediate inhibitory activities. The computational predicted binding affinities correlated well with the $\mathrm{IC}_{50}$ of $\mathrm{AM}$ drugs, validating the prediction of their computational analysis. These observations establish that aminoquinoline- and aminoacridine-based AMs impair DNA-stimulated cGAS activity (Fig. 1) [112].

Furthermore, researchers postulated that AMs could inhibit IFN- $\beta$ production within the cell, based on a previously known fact that cGAS is the key cytosolic DNA sensor required for IFN- $\beta$ production in THP1 cells in response to DNA [30]. Researcher transfected THP1 cells with dsDNA in the presence or absence of different AMs and quantified IFN- $\beta$ expression by quantitative PCR. ACMA, HCQ, and CQ all inhibited IFN- $\beta$ production by THP1 cells with an IC ${ }_{50}$ dose range of 3 to $25 \mu \mathrm{M}$. At the $\mathrm{IC}_{50}$ for QC and HCQ ( $\sim 3$ and $25 \mu \mathrm{M}$, respectively), both cell viability and transfection efficiency were unaffected compared with the no-drug control, although some reduction in cell viability and/or transfection efficiency was observed at higher doses. In contrast, PQ and QN exhibited 10-fold lower potency. The order of AMD inhibitory activity in vitro and in cells was very similar, consistent with DNA/cGAS interaction as the target. Interference with other pathways also was noted; although the concentration of HCQ to achieve $50 \%$ inhibition of IFN- $\beta$ production was higher than the 1-2 $\mu \mathrm{M}$ detected in the blood of patients, it was reported that HCQ is concentrated 10100-fold in the cell during long-term treatment [103]. QC was reported to be more effective than HCQ, and these drugs take weeks to months to exert their clinical effect in SLE [103], suggesting that concentration within the cell is required. This preliminary study activity relationship suggested that the rational design of more potent and specific cGAS inhibitors of the aminoacridine and aminoquinoline families may be possible. The structure activity relationship for AMCA core was performed highlighting the fact that substituting at the amine end of acridin-9-amine core with long chains resulted in inhibitors with better potency, as compared to cases where substituent are bulky groups. The key of the design lies in the torsional freedom of the substituents (Fig 2).

\section{Conclusion and future perspective}

Since the efficacy of various AMs may depend on a quite selective targeting of different mechanisms, ranging from the interference with TLR binding in lysosomes to the inhibition of cGAS in the cytosol, future studies are needed to address which of these action has the greater antinflammatory potential in SLE. In fact, whilst HCQ has a stronger capacity of influencing the phagosome $\mathrm{pH}$ and the function of TLR9, mepacrine may be more effective as cGAS inhibitor. Moreover, the differential action of AMs may depend also on their concentration that they reach in different cells and compartments. Thus, it will be important developing reliable computed chemistry models to predict how molecular changes will affect the different mechanisms of action of the drugs, as well as its concentration in tissues and cell compartments. On wet, or at a preclinical level, the study of the action of modified AMs in monogenic interferonopathies may provide significant knowledge to foster the development of novel drugs. 


\section{Figures.}

Figure 1. Validated $\mathrm{IC}_{50}(\mu \mathrm{M})$ of antimalarials (extracted from An J et al, J Immunol 2015 [112])<smiles>COc1ccc2nc3cc(Cl)ccc3c(N)c2c1</smiles>

ACMA, 9-amino-6-chloro-2-methoxyacridine

$\mathrm{IC}_{50}$ (cGAMP Activity) $=32 \mathrm{uM}$<smiles>CCN(CC)CCCC(C)Nc1ccnc2cc(Cl)ccc12</smiles>

$\mathrm{CQ}$, chloroquine

$\mathrm{IC}_{50}$ (cGAMP Activity) = $823 \mathrm{uM}$<smiles>CCN(CCO)CCCC(C)Nc1ccnc2cc(Cl)ccc12</smiles>

$\mathrm{HCQ}$, hydroxychloroquine $I_{50}$ (cGAMP Activity) $=354 \mathrm{uM}$<smiles>CCCCCCC(C)OC(C)=O</smiles>
QC, quinacrine $\mathrm{IC}_{50}$ (cGAMP Activity) $=13 \mathrm{uM}$<smiles>COc1cc(NC(C)CCCN)c2ncccc2c1</smiles>

$P Q$, primaquine

$I_{50}$ (cGAMP Activity) $=823$ uM<smiles>C=CC1CN2CC[C@H]1[C@H]([C@H](O)c1ccnc3ccc(OC)cc13)C2</smiles>

QN, quinine

$I_{50}$ (cGAMP Activity) = 2063 uM 
Figure 2. Possible substitutions at the amine end of acridin-9-amine core and corresponding $\mathrm{IC}_{50}(\mu \mathrm{M})$ and toxicity $(\mu \mathrm{M})$. Toxicity was reported as average of 3 cell lines @ 50\% cell death and the reference was QC with a toxicity value of 33.0 uM. (extracted from An J et al, J Immunol 2015 [112])

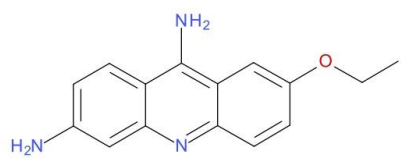

$\mathrm{IC}_{50}$ (GAMP Activity) $=10 \mathrm{uM}$

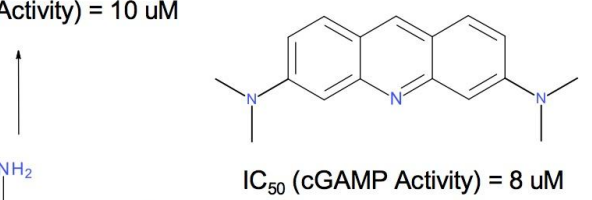

$\mathrm{R}=$
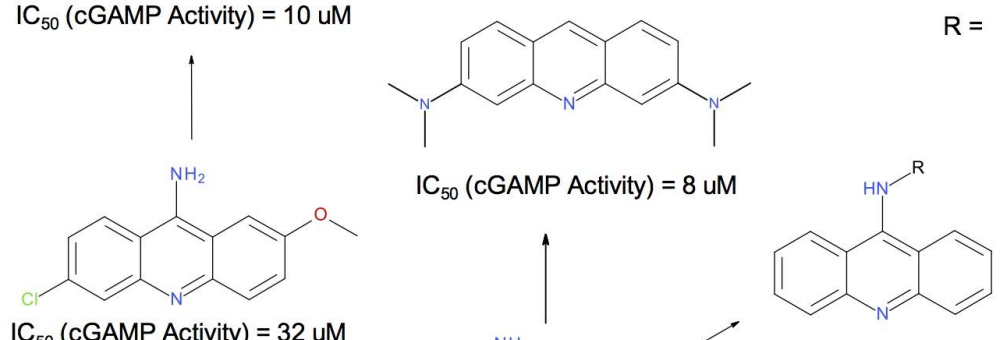

$\mathrm{IC}_{50}$ (GAMP Activity) $=8 \mathrm{uM}$

$\mathrm{IC}_{50}$ (GAMP Activity) $=32 \mathrm{uM}$ $\mathrm{IC}_{50}$ (GAMP Activity) $>650 \mathrm{uM}$
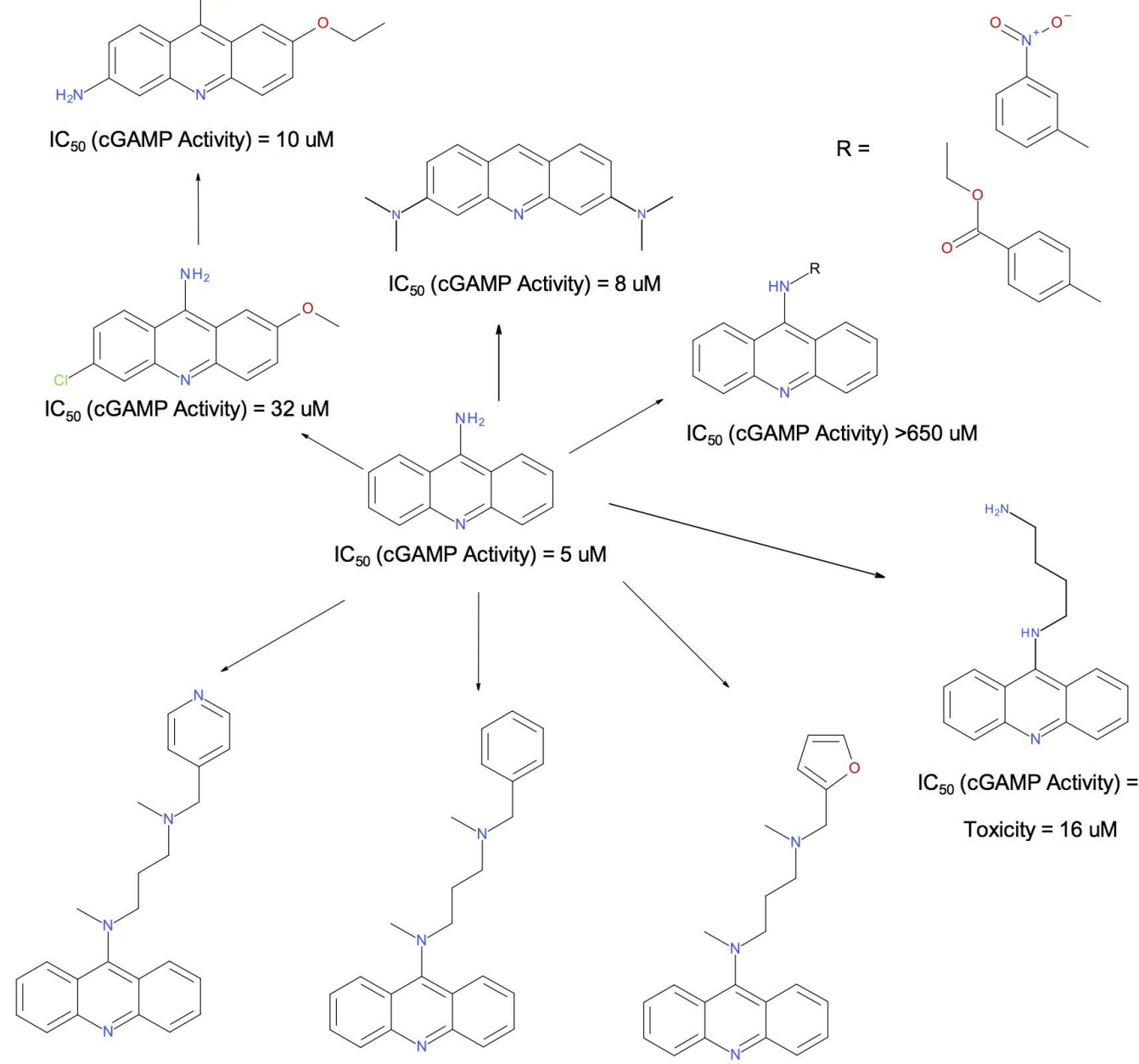

$$
\mathrm{IC}_{50} \text { (GAMP Activity) }=1 \mathrm{uM}
$$

Toxicity $=16 \mathrm{uM}$

$$
\mathrm{IC}_{50} \text { (GAMP Activity) }=23 \mathrm{uM}
$$

Toxicity $=27.4 \mathrm{uM}$
$I_{50}$ (chAMP Activity) $=18 \mathrm{uM}$

Toxicity $=33.1 \mathrm{uM}$

13 


\section{References}

[1] Jarcho, S. Quinine's predecessor: Francesco Torti and the early history of Cinchona. Johns Hopkins University Press: Baltimore, MD, 1993.

[2] Gachelin, G.; Garner, P.; Ferroni, E.; Tröhler, U.; Chalmers, I. Evaluating Cinchona bark and quinine for treating and preventing malaria. J. R. Soc. Med., 2017, 110(2), 73-82.

[3] Goss, A., Building the world's supply of quinine: Dutch colonialism and the origins of a global pharmaceutical industry. Endeavour, 2014, 38(1), 8-18.

[4] Meshnick, S. R.; Dobson, M. J. The History of Antimalarial Drugs. In Antimalarial Chemotherapy: Mechanisms of Action, Resistance, and New Directions in Drug Discovery, Rosenthal, P. J., Ed.; Humana Press: Totowa, New Jersey, USA 2001; pp 15-25.

[5] Pai-Dhungat, J. V., Caventou, Pelletier \&-- History Of Quinine. J. Assoc. Physicians India, 2015, $63(3), 58$.

[6] Ramann, G. A.; Cowen, B. J. Recent Advances in Metal-Free Quinoline Synthesis. Molecules, $2016,21(8), 986$.

[7] Hays, C. W. The United States Army and malaria control in World War II. Parassitologia, 2000, 42(1-2), 4752.

[8] Greenwood, D. Conflicts of interest: the genesis of synthetic antimalarial agents in peace and war. J. Antimicrob. Chemother., 1995, 36(5), 857-872.

[9] An, J.; Minie, M.; Sasaki, T.; Woodward, J. J.; Elkon, K. B. Antimalarial Drugs as Immune Modulators: New Mechanisms for Old Drugs. Annu. Rev. Med., 2017, 68, 317-330.

[10] James, J. A.; Kim-Howard, X. R.; Bruner, B. F.; Jonsson, M. K.; McClain, M. T.; Arbuckle, M. R.; Walker, C.; Dennis, G. J.; Merrill, J. T.; Harley, J. B. Hydroxychloroquine sulfate treatment is associated with later onset of systemic lupus erythematosus. Lupus, 2007, 16(6), 401-409.

[11] Page, F. Treatment of lupus erythematosus with mepacrine. Lancet, 1951, 2(6687), 755-758.

[12] Christiansen, J. V. Treatment of lupus erythematosus with chloroquine; therapeutic results and a comparison of the value of chloroquine and mepacrine. Br. J. Dermatol., 1957, 69(5), 157-168.

[13] Conner, S. K. Systemic lupus erythematosus; a report on twelve cases treated with quinacrine (atabrine) and chloroquine (aralen). Ann. Rheum. Dis., 1957, 16(1), 76-81.

[14] Crow, Y. J. Type I interferonopathies: a novel set of inborn errors of immunity. Ann. N. Y. Acad. Sci., 2011, $1238,91-98$.

[15] Rodero, M. P.; Crow, Y. J. Type I interferon-mediated monogenic autoinflammation: The type I interferonopathies, a conceptual overview. J. Exp. Med., 2016, 213(12), 2527-2538.

[16] Aicardi, J.; Goutières, F., A progressive familial encephalopathy in infancy with calcifications of the basal ganglia and chronic cerebrospinal fluid lymphocytosis. Ann. Neurol., 1984, 15(1), 49-54.

[17] Crow, Y. J.; Manel, N. Aicardi-Goutières syndrome and the type I interferonopathies. Nat. Rev. Immunol., 2015, 15(7), 429-440.

[18] Crow, Y. J.; Hayward, B. E.; Parmar, R.; Robins, P.; Leitch, A.; Ali, M.; Black, D. N.; van Bokhoven, H.; Brunner, H. G.; Hamel, B. C.; Corry, P. C.; Cowan, F. M.; Frints, S. G.; Klepper, J.; Livingston, J. H.; Lynch, S. A.; Massey, R. F.; Meritet, J. F.; Michaud, J. L.; Ponsot, G.; Voit, T.; Lebon, P.; Bonthron, D. T.; Jackson, A. P.; Barnes, D. E.; Lindahl, T. Mutations in the gene encoding the 3'-5' DNA exonuclease TREX1 cause AicardiGoutières syndrome at the AGS1 locus. Nat. Genet., 2006, 38(8), 917-920.

[19] Crow, Y. J.; Leitch, A.; Hayward, B. E.; Garner, A.; Parmar, R.; Griffith, E.; Ali, M.; Semple, C.; Aicardi, J.; Babul-Hirji, R.; Baumann, C.; Baxter, P.; Bertini, E.; Chandler, K. E.; Chitayat, D.; Cau, D.; Déry, C.; Fazzi, E.; 
Goizet, C.; King, M. D.; Klepper, J.; Lacombe, D.; Lanzi, G.; Lyall, H.; Martínez-Frías, M. L.; Mathieu, M.; McKeown, C.; Monier, A.; Oade, Y.; Quarrell, O. W.; Rittey, C. D.; Rogers, R. C.; Sanchis, A.; Stephenson, J. B.; Tacke, U.; Till, M.; Tolmie, J. L.; Tomlin, P.; Voit, T.; Weschke, B.; Woods, C. G.; Lebon, P.; Bonthron, D. T.; Ponting, C. P.; Jackson, A. P. Mutations in genes encoding ribonuclease H2 subunits cause Aicardi-Goutières syndrome and mimic congenital viral brain infection. Nat. Genet., 2006, 38(8), 910-916.

[20] Rice, G. I.; Kasher, P. R.; Forte, G. M.; Mannion, N. M.; Greenwood, S. M.; Szynkiewicz, M.; Dickerson, J. E.; Bhaskar, S. S.; Zampini, M.; Briggs, T. A.; Jenkinson, E. M.; Bacino, C. A.; Battini, R.; Bertini, E.; Brogan, P. A.; Brueton, L. A.; Carpanelli, M.; De Laet, C.; de Lonlay, P.; del Toro, M.; Desguerre, I.; Fazzi, E.; GarciaCazorla, A.; Heiberg, A.; Kawaguchi, M.; Kumar, R.; Lin, J. P.; Lourenco, C. M.; Male, A. M.; Marques, W.; Mignot, C.; Olivieri, I.; Orcesi, S.; Prabhakar, P.; Rasmussen, M.; Robinson, R. A.; Rozenberg, F.; Schmidt, J. L.; Steindl, K.; Tan, T. Y.; van der Merwe, W. G.; Vanderver, A.; Vassallo, G.; Wakeling, E. L.; Wassmer, E.; Whittaker, E.; Livingston, J. H.; Lebon, P.; Suzuki, T.; McLaughlin, P. J.; Keegan, L. P.; O'Connell, M. A.; Lovell, S. C.; Crow, Y. J. Mutations in ADAR1 cause Aicardi-Goutières syndrome associated with a type I interferon signature. Nat. Genet., 2012, 44(11), 1243-1248.

[21] Rice, G. I.; Bond, J.; Asipu, A.; Brunette, R. L.; Manfield, I. W.; Carr, I. M.; Fuller, J. C.; Jackson, R. M.; Lamb, T.; Briggs, T. A.; Ali, M.; Gornall, H.; Couthard, L. R.; Aeby, A.; Attard-Montalto, S. P.; Bertini, E.; Bodemer, C.; Brockmann, K.; Brueton, L. A.; Corry, P. C.; Desguerre, I.; Fazzi, E.; Cazorla, A. G.; Gener, B.; Hamel, B. C.; Heiberg, A.; Hunter, M.; van der Knaap, M. S.; Kumar, R.; Lagae, L.; Landrieu, P. G.; Lourenco, C. M.; Marom, D.; McDermott, M. F.; van der Merwe, W.; Orcesi, S.; Prendiville, J. S.; Rasmussen, M.; Shalev, S. A.; Soler, D. M.; Shinawi, M.; Spiegel, R.; Tan, T. Y.; Vanderver, A.; Wakeling, E. L.; Wassmer, E.; Whittaker, E.; Lebon, P.; Stetson, D. B.; Bonthron, D. T.; Crow, Y. J. Mutations involved in Aicardi-Goutières syndrome implicate SAMHD1 as regulator of the innate immune response. Nat. Genet., 2009, 41(7), 829-832.

[22] Rice, G. I.; del Toro Duany, Y.; Jenkinson, E. M.; Forte, G. M.; Anderson, B. H.; Ariaudo, G.; Bader-Meunier, B.; Baildam, E. M.; Battini, R.; Beresford, M. W.; Casarano, M.; Chouchane, M.; Cimaz, R.; Collins, A. E.; Cordeiro, N. J.; Dale, R. C.; Davidson, J. E.; De Waele, L.; Desguerre, I.; Faivre, L.; Fazzi, E.; Isidor, B.; Lagae, L.; Latchman, A. R.; Lebon, P.; Li, C.; Livingston, J. H.; Lourenço, C. M.; Mancardi, M. M.; Masurel-Paulet, A.; McInnes, I. B.; Menezes, M. P.; Mignot, C.; O'Sullivan, J.; Orcesi, S.; Picco, P. P.; Riva, E.; Robinson, R. A.; Rodriguez, D.; Salvatici, E.; Scott, C.; Szybowska, M.; Tolmie, J. L.; Vanderver, A.; Vanhulle, C.; Vieira, J. P.; Webb, K.; Whitney, R. N.; Williams, S. G.; Wolfe, L. A.; Zuberi, S. M.; Hur, S.; Crow, Y. J. Gain-of-function mutations in IFIH1 cause a spectrum of human disease phenotypes associated with upregulated type I interferon signaling. Nat. Genet., 2014, 46(5), 503-509.

[23] Oda, H.; Nakagawa, K.; Abe, J.; Awaya, T.; Funabiki, M.; Hijikata, A.; Nishikomori, R.; Funatsuka, M.; Ohshima, Y.; Sugawara, Y.; Yasumi, T.; Kato, H.; Shirai, T.; Ohara, O.; Fujita, T.; Heike, T. Aicardi-Goutières syndrome is caused by IFIH1 mutations. Am. J. Hum. Genet., 2014, 95(1), 121-125.

[24] Liu, Y.; Jesus, A. A.; Marrero, B.; Yang, D.; Ramsey, S. E.; Montealegre Sanchez, G. A.; Tenbrock, K.; Wittkowski, H.; Jones, O. Y.; Kuehn, H. S.; Lee, C. C.; DiMattia, M. A.; Cowen, E. W.; Gonzalez, B.; Palmer, I.; DiGiovanna, J. J.; Biancotto, A.; Kim, H.; Tsai, W. L.; Trier, A. M.; Huang, Y.; Stone, D. L.; Hill, S.; Kim, H. J.; St Hilaire, C.; Gurprasad, S.; Plass, N.; Chapelle, D.; Horkayne-Szakaly, I.; Foell, D.; Barysenka, A.; Candotti, F.; Holland, S. M.; Hughes, J. D.; Mehmet, H.; Issekutz, A. C.; Raffeld, M.; McElwee, J.; Fontana, J. R.; Minniti, C. P.; Moir, S.; Kastner, D. L.; Gadina, M.; Steven, A. C.; Wingfield, P. T.; Brooks, S. R.; 
Rosenzweig, S. D.; Fleisher, T. A.; Deng, Z.; Boehm, M.; Paller, A. S.; Goldbach-Mansky, R. Activated STING in a vascular and pulmonary syndrome. N. Engl. J. Med., 2014, 371(6), 507-18.

[25] Zhang, X.; Bogunovic, D.; Payelle-Brogard, B.; Francois-Newton, V.; Speer, S. D.; Yuan, C.; Volpi, S.; Li, Z.; Sanal, O.; Mansouri, D.; Tezcan, I.; Rice, G. I.; Chen, C.; Mansouri, N.; Mahdaviani, S. A.; Itan, Y.; Boisson, B.; Okada, S.; Zeng, L.; Wang, X.; Jiang, H.; Liu, W.; Han, T.; Liu, D.; Ma, T.; Wang, B.; Liu, M.; Liu, J. Y.; Wang, Q. K.; Yalnizoglu, D.; Radoshevich, L.; Uzé, G.; Gros, P.; Rozenberg, F.; Zhang, S. Y.; Jouanguy, E.; Bustamante, J.; García-Sastre, A.; Abel, L.; Lebon, P.; Notarangelo, L. D.; Crow, Y. J.; Boisson-Dupuis, S.; Casanova, J. L.; Pellegrini, S. Human intracellular ISG15 prevents interferon- $\alpha / \beta$ over-amplification and autoinflammation. Nature, 2015, 517(7532), 89-93.

[26] Kim, H.; Sanchez, G. A.; Goldbach-Mansky, R. Insights from Mendelian Interferonopathies: Comparison of CANDLE, SAVI with AGS, Monogenic Lupus. J. Mol. Med. (Berl), 2016, 94(10), 1111-1127.

[27] Rice, G. I.; Forte, G. M.; Szynkiewicz, M.; Chase, D. S.; Aeby, A.; Abdel-Hamid, M. S.; Ackroyd, S.; Allcock, R.; Bailey, K. M.; Balottin, U.; Barnerias, C.; Bernard, G.; Bodemer, C.; Botella, M. P.; Cereda, C.; Chandler, K. E.; Dabydeen, L.; Dale, R. C.; De Laet, C.; De Goede, C. G.; Del Toro, M.; Effat, L.; Enamorado, N. N.; Fazzi, E.; Gener, B.; Haldre, M.; Lin, J. P.; Livingston, J. H.; Lourenco, C. M.; Marques, W.; Oades, P.; Peterson, P.; Rasmussen, M.; Roubertie, A.; Schmidt, J. L.; Shalev, S. A.; Simon, R.; Spiegel, R.; Swoboda, K. J.; Temtamy, S. A.; Vassallo, G.; Vilain, C. N.; Vogt, J.; Wermenbol, V.; Whitehouse, W. P.; Soler, D.; Olivieri, I.; Orcesi, S.; Aglan, M. S.; Zaki, M. S.; Abdel-Salam, G. M.; Vanderver, A.; Kisand, K.; Rozenberg, F.; Lebon, P.; Crow, Y. J. Assessment of interferon-related biomarkers in Aicardi-Goutières syndrome associated with mutations in TREX1, RNASEH2A, RNASEH2B, RNASEH2C, SAMHD1, and ADAR: a case-control study. Lancet Neurol., 2013, 12(12), 1159-1169.

[28] Mackay, M.; Oswald, M.; Sanchez-Guerrero, J.; Lichauco, J.; Aranow, C.; Kotkin, S.; Korsunsky, I.; Gregersen, P. K.; Diamond, B. Molecular signatures in systemic lupus erythematosus: distinction between disease flare and infection. Lupus Sci. Med., 2016, 3(1), e000159.

[29] Sun, L.; Wu, J.; Du, F.; Chen, X.; Chen, Z. J. Cyclic GMP-AMP synthase is a cytosolic DNA sensor that activates the type I interferon pathway. Science, 2013, 339(6121), 786-791.

[30] Wu, J.; Sun, L.; Chen, X.; Du, F.; Shi, H.; Chen, C.; Chen, Z. J. Cyclic GMP-AMP is an endogenous second messenger in innate immune signaling by cytosolic DNA. Science, 2013, 339(6121), 826-830.

[31] Ishikawa, H.; Barber, G. N. STING is an endoplasmic reticulum adaptor that facilitates innate immune signalling. Nature, 2008, 455(7213), 674-678.

[32] Schafer, S. L.; Lin, R.; Moore, P. A.; Hiscott, J.; Pitha, P. M. Regulation of type I interferon gene expression by interferon regulatory factor-3. J. Biol. Chem., 1998, 273(5), 2714-2720.

[33] Tanaka, Y.; Chen, Z. J., STING specifies IRF3 phosphorylation by TBK1 in the cytosolic DNA signaling pathway. Sci. Signal., 2012, 5(214), ra20.

[34] Volpi, S.; Picco, P.; Caorsi, R.; Candotti, F.; Gattorno, M. Type I interferonopathies in pediatric rheumatology. Pediatr. Rheumatol. Online, J 2016, 14(1), 35.

[35] Mok, C. C.; Lau, C. S. Pathogenesis of systemic lupus erythematosus. J. Clin. Pathol., 2003, 56(7), 481-490.

[36] Deng, Y.; Tsao, B. P. Genetic susceptibility to systemic lupus erythematosus in the genomic era. Nat. Rev. Rheumatol., 2010, 6(12), 683-692.

[37] Hooks, J. J.; Moutsopoulos, H. M.; Geis, S. A.; Stahl, N. I.; Decker, J. L.; Notkins, A. L. Immune interferon in the circulation of patients with autoimmune disease. N. Engl. J. Med., 1979, 301(1), 5-8. 
[38] Rus, V.; Atamas, S. P.; Shustova, V.; Luzina, I. G.; Selaru, F.; Magder, L. S.; Via, C. S. Expression of cytokineand chemokine-related genes in peripheral blood mononuclear cells from lupus patients by cDNA array. Clin. Immunol., 2002, 102(3), 283-290.

[39] Maas, K.; Chan, S.; Parker, J.; Slater, A.; Moore, J.; Olsen, N.; Aune, T. M. Cutting edge: molecular portrait of human autoimmune disease. J. Immunol., 2002, 169(1), 5-9.

[40] Crow, M. K.; Wohlgemuth, J. Microarray analysis of gene expression in lupus. Arthritis. Res. Ther., 2003, 5(6), 279-287.

[41] Bennett, L.; Palucka, A. K.; Arce, E.; Cantrell, V.; Borvak, J.; Banchereau, J.; Pascual, V. Interferon and granulopoiesis signatures in systemic lupus erythematosus blood. J. Exp. Med., 2003, 197(6), 711-723.

[42] Theofilopoulos, A. N.; Dixon, F. J. Murine models of systemic lupus erythematosus. Adv. Immunol., 1985, 37 , 269-390.

[43] Crow, M. K.; Kirou, K. A. Interferon-alpha in systemic lupus erythematosus. Curr. Opin. Rheumatol., 2004, $16(5), 541-547$.

[44] Crow, M. K. Type I interferon in the pathogenesis of lupus. J. Immunol. 2014, 192(12), 5459-5468.

[45] Feng, X.; Wu, H.; Grossman, J. M.; Hanvivadhanakul, P.; FitzGerald, J. D; Park, G. S.; Dong, X.; Chen, W.; Kim, M. H.; Weng, H. H.; Furst, D. E.; Gorn, A.; McMahon, M.; Taylor, M.; Brahn, E.; Hahn, B. H.; Tsao, B. P. Association of increased interferon-inducible gene expression with disease activity and lupus nephritis in patients with systemic lupus erythematosus. Arthritis. Rheum., 2006, 54(9), 2951-2962.

[46] Landolt-Marticorena, C.; Bonventi, G.; Lubovich, A.; Ferguson, C.; Unnithan, T.; Su, J.; Gladman, D. D.; Urowitz, M.; Fortin, P. R.; Wither, J. Lack of association between the interferon-alpha signature and longitudinal changes in disease activity in systemic lupus erythematosus. Ann. Rheum. Dis., 2009, 68(9), 1440-1446.

[47] Petri, M.; Singh, S.; Tesfasyone, H.; Dedrick, R.; Fry, K.; Lal, P.; Williams, G.; Bauer, J.; Gregersen, P.; Behrens, T.; Baechler, E. Longitudinal expression of type I interferon responsive genes in systemic lupus erythematosus. Lupus, 2009, 18(11), 980-989.

[48] Farkas, L.; Beiske, K.; Lund-Johansen, F.; Brandtzaeg, P.; Jahnsen, F. L. Plasmacytoid dendritic cells (natural interferon- alpha/beta-producing cells) accumulate in cutaneous lupus erythematosus lesions. Am. J. Pathol., 2001, 159(1), 237-243.

[49] Tucci, M.; Quatraro, C.; Lombardi, L.; Pellegrino, C.; Dammacco, F.; Silvestris, F. Glomerular accumulation of plasmacytoid dendritic cells in active lupus nephritis: role of interleukin-18. Arthritis. Rheum., 2008, 58(1), 251262.

[50] Nzeusseu Toukap, A.; Galant, C.; Theate, I.; Maudoux, A. L.; Lories, R. J.; Houssiau, F. A.; Lauwerys, B. R. Identification of distinct gene expression profiles in the synovium of patients with systemic lupus erythematosus. Arthritis. Rheum., 2007, 56(5), 1579-1588.

[51] Robinson, A. B.; Reed, A. M. Clinical features, pathogenesis and treatment of juvenile and adult dermatomyositis. Nat. Rev. Rheumatol., 2011, 7(11), 664-675.

[52] Tansley, S. L.; McHugh, N. J.; Wedderburn, L. R. Adult and juvenile dermatomyositis: are the distinct clinical features explained by our current understanding of serological subgroups and pathogenic mechanisms? Arthritis Res. Ther., 2013, 15(2), 211.

[53] Baechler, E. C.; Bauer, J. W.; Slattery, C. A.; Ortmann, W. A.; Espe, K. J.; Novitzke, J.; Ytterberg, S. R.; Gregersen, P. K.; Behrens, T. W.; Reed, A. M. An interferon signature in the peripheral blood of dermatomyositis patients is associated with disease activity. Mol. Med., 2007, 13(1-2), 59-68. 
[54] Greenberg, S. A.; Pinkus, J. L.; Pinkus, G. S.; Burleson, T.; Sanoudou, D.; Tawil, R.; Barohn, R. J.; Saperstein, D. S.; Briemberg, H. R.; Ericsson, M.; Park, P.; Amato, A. A. Interferon-alpha/beta-mediated innate immune mechanisms in dermatomyositis. Ann. Neurol., 2005, 57(5), 664-678.

[55] Salajegheh, M.; Kong, S. W.; Pinkus, J. L.; Walsh, R. J.; Liao, A.; Nazareno, R.; Amato, A. A.; Krastins, B.; Morehouse, C.; Higgs, B. W.; Jallal, B.; Yao, Y.; Sarracino, D. A.; Parker, K. C.; Greenberg, S. A. Interferonstimulated gene 15 (ISG15) conjugates proteins in dermatomyositis muscle with perifascicular atrophy. Ann. Neurol., 2010, 67(1), 53-63.

[56] Greenberg, S. A. Dermatomyositis and type 1 interferons. Curr. Rheumatol. Rep., 2010, 12(3), $198-203$.

[57] McNiff, J. M.; Kaplan, D. H. Plasmacytoid dendritic cells are present in cutaneous dermatomyositis lesíons in a pattern distinct from lupus erythematosus. J. Cutan. Pathol., 2008, 35(5), 452-456.

[58] Suarez-Almazor, M. E.; Belseck, E.; Shea, B.; Homik, J.; Wells, G.; Tugwell, P. Antimalarials for treating rheumatoid arthritis. Cochrane Database Syst. Rev., 2000, (4), CD000959.

[59] Cavazzana, I.; Sala, R.; Bazzani, C.; Ceribelli, A.; Zane, C.; Cattaneo, R.; Tincani, A.; Calzavara-Pinton, P. G.; Franceschini, F. Treatment of lupus skin involvement with quinacrine and hydroxychloroquine. Lupus, 2009, $18(8), 735-739$.

[60] Rosenbaum, J. T.; Mount, G. R.; Youssef, J.; Lin, P. New Perspectives in Rheumatology: Avoiding Antimalarial Toxicity. Arthritis Rheumatol., 2016, 68(8), 1805-1809.

[61] ClinicalTrials.gov. http://www.clinicaltrials.gov/ (accessed April 14, 2017).

[62] Takeshige, K.; Baba, M.; Tsuboi, S.; Noda, T.; Ohsumi, Y. Autophagy in yeast demonstrated with proteinasedeficient mutants and conditions for its induction. J. Cell. Biol., 1992, 119(2), 301-311.

[63] Nakamura, S.; Yoshimori, T. New insights into autophagosome-lysosome fusion. J. Cell. Sci., 2017, 130(7), 1209-1216.

[64] Lippai, M.; Szatmári, Z. Autophagy-from molecular mechanisms to clinical relevance. Cell. Biol. Toxicol., 2017, 33(2), 145-168.

[65] de Duve, C.; de Barsy, T.; Poole, B.; Trouet, A.; Tulkens, P.; Van Hoof, F. Commentary. Lysosomotropic agents. Biochem. Pharmacol., 1974, 23(18), 2495-2531.

[66] Lie, S. O.; Schofield, B. Inactivation of lysosomal function in normal cultured human fibroblasts by chloroquine. Biochem. Pharmacol., 1973, 22(23), 3109-3114.

[67] Al-Bari, M. A. Chloroquine analogues in drug discovery: new directions of uses, mechanisms of actions and toxic manifestations from malaria to multifarious diseases. J. Antimicrob. Chemother., 2015, 70(6), 1608-1621.

[68] Kalia, S.; Dutz, J. P. New concepts in antimalarial use and mode of action in dermatology. Dermatol. Ther., 2007, 20(4), 160-174.

[69] Jang, C. H.; Choi, J. H.; Byun, M. S.; Jue, D. M. Chloroquine inhibits production of TNF-alpha, IL-1beta and IL-6 from lipopolysaccharide-stimulated human monocytes/macrophages by different modes. Rheumatology (Oxford), 2006, 45(6), 703-710.

[70] Clancy, R. M.; Markham, A. J.; Buyon, J. P. Endosomal Toll-like receptors in clinically overt and silent autoimmunity. Immunol. Rev., 2016, 269(1), 76-84.

[71] Celhar, T.; Magalhães, R.; Fairhurst, A. M. TLR7 and TLR9 in SLE: when sensing self goes wrong. Immunol. Res., 2012, 53(1-3), 58-77.

[72] Gao, D.; Li, T.; Li, X. D.; Chen, X.; Li, Q. Z.; Wight-Carter, M.; Chen, Z. J. Activation of cyclic GMP-AMP synthase by self-DNA causes autoimmune diseases. Proc. Natl. Acad. Sci. U.S.A., 2015, 112(42), E5699-5705. 
[73] Kuznik, A.; Bencina, M.; Svajger, U.; Jeras, M.; Rozman, B.; Jerala, R. Mechanism of endosomal TLR inhibition by antimalarial drugs and imidazoquinolines. J. Immunol., 2011, 186(8), 4794-4804.

[74] Sun, S.; Rao, N. L.; Venable, J.; Thurmond, R.; Karlsson, L. TLR7/9 antagonists as therapeutics for immunemediated inflammatory disorders. Inflamm. Allergy Drug. Targets, 2007, 6(4), 223-235.

[75] Rutz, M.; Metzger, J.; Gellert, T.; Luppa, P.; Lipford, G. B.; Wagner, H.; Bauer, S. Toll-like receptor 9 binds single-stranded CpG-DNA in a sequence- and pH-dependent manner. Eur. J. Immunol., 2004, 34(9), 2541-2550.

[76] Hennessy, E. J.; Parker, A. E.; O'Neill, L. A. Targeting Toll-like receptors: emerging therapeutics? Nat. Rev. Drug. Discov., 2010, 9(4), 293-307.

[77] Ablasser, A.; Hemmerling, I.; Schmid-Burgk, J. L.; Behrendt, R.; Roers, A.; Hornung, V. TREX1 deficiency triggers cell-autonomous immunity in a cGAS-dependent manner. J. Immunol., 2014, 192(12), 5993-5997.

[78] Gentili, M.; Manel, N. cGAS-STING do it again: pivotal role in RNase H2 genetic disease. EMBO J., 2016, 35(8), 796-797.

[79] Block, J. A. Hydroxychloroquine and retinal safety. Lancet, 1998, 351(9105), 771.

[80] Scherbel, A. L.; Schuchter, S. L.; Harrison, J. W. Comparison of effects of two antimalarial agents, hydroxychloroquine sulfate and chloroquine phosphate, in patients with rheumatoid arthitis. Cleve. Clin. $Q$., 1957, 24(2), 98-104.

[81] Rainsford, K. D.; Parke, A. L.; Clifford-Rashotte, M.; Kean, W. F. Therapy and pharmacological properties of hydroxychloroquine and chloroquine in treatment of systemic lupus erythematosus, rheumatoid arthritis and related diseases. Inflammopharmacology, 2015, 23(5), 231-269.

[82] Easterbrook, M. Is corneal deposition of antimalarial any indication of retinal toxicity? Can. J. Ophthalmol., 1990, 25(5), 249-251.

[83] Rynes, R. I.; Bernstein, H. N. Ophthalmologic safety profile of antimalarial drugs. Lupus, 1993, 2 Suppl 1, S1719.

[84] Rynes, R. I. Hydroxychloroquine treatment of rheumatoid arthritis. Am. J. Med., 1988, 85(4A), $18-22$.

[85] Tehrani, R.; Ostrowski, R. A.; Hariman, R.; Jay, W. M. Ocular toxicity of hydroxychloroquine. Semin. Ophthalmol., 2008, 23(3), 201-209.

[86] Geamănu Pancă, A.; Popa-Cherecheanu, A.; Marinescu, B.; Geamănu, C. D.; Voinea, L. M. Retinal toxicity associated with chronic exposure to hydroxychloroquine and its ocular screening. J. Med. Life, 2014, 7(3), 322326.

[87] Leoni, A. Effect of chloroquine on erythematous response to phenol in chronic lupus erythematosus. Minerva Dermatol., 1955, 30(12), 410-411.

[88] Adelusi, S. A.; Salako, L. A. Tissue and blood concentrations of chloroquine following chronic administration in the rat. J. Pharm. Pharmacol., 1982, 34(11), 733-735.

[89] Ducharme, J.; Farinotti, R. Clinical pharmacokinetics and metabolism of chloroquine. Focus on recent advancements. Clin. Pharmacokinet., 1996, 31(4), 257-274.

[90] Akintonwa, A.; Gbajumo, S. A.; Mabadeje, A. F. Placental and milk transfer of chloroquine in humans. Ther. Drug Monit., 1988, 10(2), 147-149.

[91] Costedoat-Chalumeau, N.; Amoura, Z.; Aymard, G.; Le, T. H.; Wechsler, B.; Vauthier, D.; Dermer, M. E.; Darbois, Y.; Piette, J. C. Evidence of transplacental passage of hydroxychloroquine in humans. Arthritis. Rheum., 2002, 46(4), 1123-1124. 
[92] Li, X. Q.; Björkman, A.; Andersson, T. B.; Gustafsson, L. L.; Masimirembwa, C. M. Identification of human cytochrome $\mathrm{P}(450) \mathrm{s}$ that metabolise anti-parasitic drugs and predictions of in vivo drug hepatic clearance from in vitro data. Eur. J. Clin. Pharmacol., 2003, 59(5-6), 429-442.

[93] Churchill, F. C.; Mount, D. L.; Schwartz, I. K. Determination of chloroquine and its major metabolite in blood using perfluoroacylation followed by fused-silica capillary gas chromatography with nitrogen-sensitive detection. J. Chromatogr., 1983, 274, 111-120.

[94] McChesney, E. W. Animal toxicity and pharmacokinetics of hydroxychloroquine sulfate. Am. J. Med., 1983, 75(1A), 11-18.

[95] Furst, D. E. Pharmacokinetics of hydroxychloroquine and chloroquine during treatment of rheumatic diseases. Lupus, 1996, 5 Suppl 1, S11-15.

[96] Cutler, D. J. Possible mechanisms of action of antimalarials in rheumatic disease. Agents Actions Suppl., 1993, 44, 139-143.

[97] Costedoat-Chalumeau, N.; Amoura, Z.; Hulot, J. S.; Hammoud, H. A.; Aymard, G.; Cacoub, P.; Francès, C.; Wechsler, B.; Huong, d. L.; Ghillani, P.; Musset, L.; Lechat, P.; Piette, J. C. Low blood concentration of hydroxychloroquine is a marker for and predictor of disease exacerbations in patients with systemic lupus erythematosus. Arthritis Rheum., 2006, 54(10), 3284-3290.

[98] Costedoat-Chalumeau, N.; Galicier, L.; Aumaître, O.; Francès, C.; Le Guern, V.; Lioté, F.; Smail, A.; Limal, N.; Perard, L.; Desmurs-Clavel, H.; Boutin, d. L.; Asli, B.; Kahn, J. E.; Pourrat, J.; Sailler, L.; Ackermann, F.; Papo, T.; Sacré, K.; Fain, O.; Stirnemann, J.; Cacoub, P.; Jallouli, M.; Leroux, G.; Cohen-Bittan, J.; Tanguy, M. L.; Hulot, J. S.; Lechat, P.; Musset, L.; Amoura, Z.; Piette, J. C.; PLUS, G. Hydroxychloroquine in systemic lupus erythematosus: results of a French multicentre controlled trial (PLUS Study). Ann. Rheum. Dis., 2013, 72(11), 1786-1792.

[99] Costedoat-Chalumeau, N.; Amoura, Z.; Hulot, J. S.; Aymard, G.; Leroux, G.; Marra, D.; Lechat, P.; Piette, J. C. Very low blood hydroxychloroquine concentration as an objective marker of poor adherence to treatment of systemic lupus erythematosus. Ann. Rheum. Dis., 2007, 66(6), 821-824.

[100] Durcan, L.; Clarke, W. A.; Magder, L. S.; Petri, M. Hydroxychloroquine Blood Levels in Systemic Lupus Erythematosus: Clarifying Dosing Controversies and Improving Adherence. J. Rheumatol., 2015, 42(11), 20922097.

[101] Munster, T.; Gibbs, J. P.; Shen, D.; Baethge, B. A.; Botstein, G. R.; Caldwell, J.; Dietz, F.; Ettlinger, R.; Golden, H. E.; Lindsley, H.; McLaughlin, G. E.; Moreland, L. W.; Roberts, W. N.; Rooney, T. W.; Rothschild, B.; Sack, M.; Sebba, A. I.; Weisman, M.; Welch, K. E.; Yocum, D.; Furst, D. E. Hydroxychloroquine concentrationresponse relationships in patients with rheumatoid arthritis. Arthritis Rheum., 2002, 46(6), 1460-1469.

[102] Campbell, W. C. The chemotherapy of parasitic infections. J. Parasitol., 1986, 72(1), 45-61.

[103] Wallace, D. J. The use of quinacrine (Atabrine) in rheumatic diseases: a reexamination. Semin. Arthritis Rheum., 1989, $18(4), 282-296$.

[104] Shannon, J. A.; Earle, D. P.; Brodie, B. B.; Taggart, J. V.; Berliner, R. The pharmacological basis for the rational use of Atabrine in the treatment of malaria. J. Pharmacol. Exp. Ther., 1944, 81(4), 307-330.

[105] Looareesuwan, S.; Phillips, R. E.; Edwards, G.; Rodick, C. L.; Chanthavanich, P.; Supanaranond, W.; Warrell, D. A. Mepacrine accumulation during treatment of chloroquine-resistant falciparum malaria. Ann. Trop. Med. Parasitol., 1988, 82(2), 107-112. 
[106] Pasqualini, R.; Koivunen, E.; Ruoslahti, E. Alpha v integrins as receptors for tumor targeting by circulating ligands. Nat. Biotechnol., 1997, 15(6), 542-546.

[107] Dubowchik, G. M.; Walker, M. A. Receptor-mediated and enzyme-dependent targeting of cytotoxic anticancer drugs. Pharmacol. Ther., 1999, 83(2), 67-123.

[108] Paulos, C. M.; Turk, M. J.; Breur, G. J.; Low, P. S. Folate receptor-mediated targeting of therapeutic and imaging agents to activated macrophages in rheumatoid arthritis. Adv. Drug. Deliv. Rev., 2004, 56(8), 1205-1217.

[109] Kontermann, R. E. Immunoliposomes for cancer therapy. Curr. Opin. Mol. Ther., 2006, 8(1), 39-45.

[110] Aouadi, M.; Tesz, G. J.; Nicoloro, S. M.; Wang, M.; Chouinard, M.; Soto, E.; Ostroff, G. R.; Czech, M. P. Orally delivered siRNA targeting macrophage Map4k4 suppresses systemic inflammation. Nature, 2009, 458(7242), 1180-1184.

[111] Needham, L. A.; Davidson, A. H.; Bawden, L. J.; Belfield, A.; Bone, E. A.; Brotherton, D. H.; Bryant, S.; Charlton, M. H.; Clark, V. L.; Davies, S. J.; Donald, A.; Day, F. A.; Krige, D.; Legris, V.; McDermott, J.; McGovern, Y.; Owen, J.; Patel, S. R.; Pintat, S.; Testar, R. J.; Wells, G. M.; Moffat, D.; Drummond, A. H. Drug targeting to monocytes and macrophages using esterase-sensitive chemical motifs. J. Pharmacol. Exp. Ther., 2011, 339(1), 132-142.

[112] An, J.; Woodward, J. J.; Sasaki, T.; Minie, M.; Elkon, K. B. Cutting edge: Antimalarial drugs inhibit IFN- $\beta$ production through blockade of cyclic GMP-AMP synthase-DNA interaction. J. Immunol., 2015, 194(9), 40894093.

[113] An, J.; Durcan, L.; Karr, R. M.; Briggs, T. A.; Rice, G. I.; Teal, T. H.; Woodward, J. J.; Elkon, K. B. Expression of Cyclic GMP-AMP Synthase in Patients With Systemic Lupus Erythematosus. Arthritis Rheumatol., 2017, 69(4), 800-807. 